\title{
Errata
}

\section{Estudo de Mecanismos de Reações Envolvendo Compostos de Telúrio Aplicações Sintéticas de Compostos Calcogenados}

Tese de doutorado defendida por ARTUR FRANZ KEPPLER

\section{Página 2, $2^{\circ}$ Esquema 2}

Deve-se ler o esquema abaixo ao invés do apresentado no corpo da tese

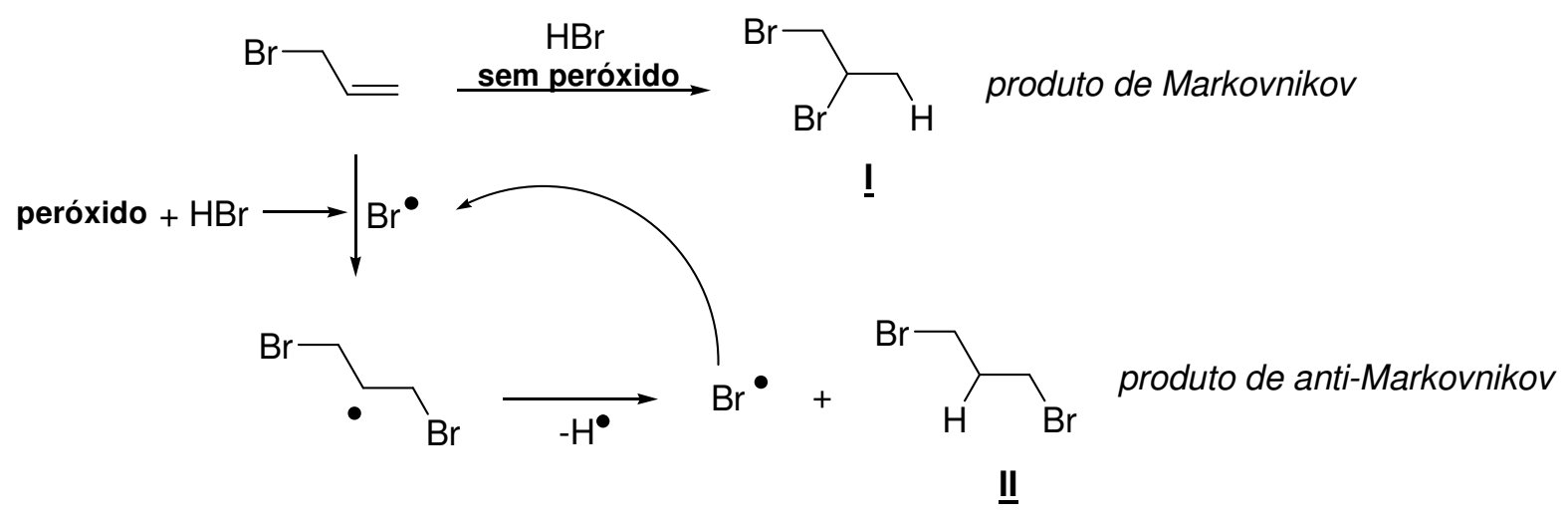

\section{Página 30, Figura 7 e Página 31, Figura 8}

A estrutura correta doscompostos $\underline{11}$ e $\underline{12}$ estão apresentadas logo abaixo

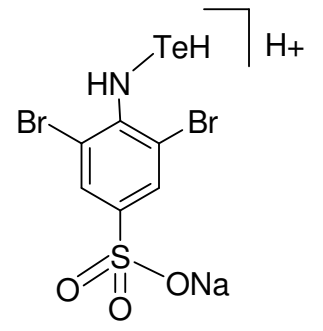

$\underline{11}$

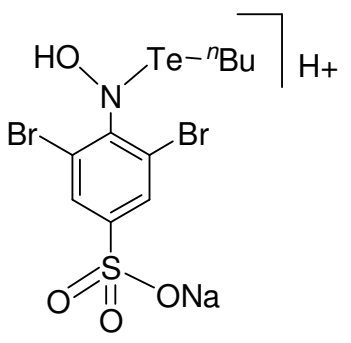

$\underline{12}$

\section{Página 34, Esquema 15}

Estruturas de ressonância dos adutos radicalares DBNBS/ ${ }^{\bullet}$ TeR (em vez de Híbridos de ressonância dos adutos radicalares $\left.\mathrm{DBNBS} /{ }^{\bullet} \mathrm{TeR}\right)$

Página $35,2^{\circ}$ parágrafo $-1^{a}$ linha

....método de hidroteluração.... (em vez de "método "hidrotelurante"”)

Página 35, $4^{\circ}$ parágrafo - $5^{a}$ linha 
..radical teluroila...(em vez de "..radical teluroil...")

\section{Página 36, $1^{\circ}$ parágrafo $-7^{a}$ linha}

...ataca a ligação $\mathrm{C} \equiv \mathrm{C}$ de $\underline{\mathbf{2 0}}$, levando a formação do radical vinílico $\underline{\mathbf{1 9}}$ que abstrai o.... (em vez de “...ataca a ligação $\mathrm{C} \equiv \mathrm{C}$ de $\underline{\mathbf{1 9}}$, levando a formação do radical vinílico $\underline{\mathbf{2 0}}$ que abstrai o...”)

\section{Página 60, Tabela 4}

Deve-se ler o esquema abaixo ao invés do apresentado no corpo da tese

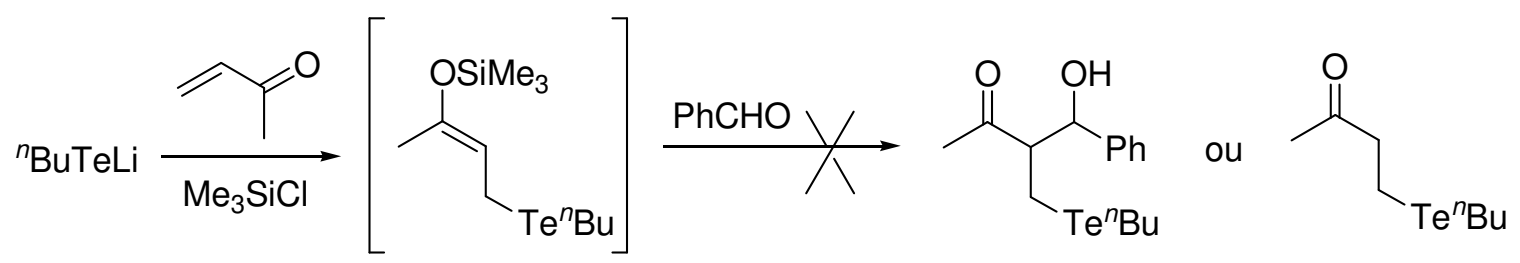

\section{Página 70, 20 parágrafo - 3a linha}

...feita a adição lenta de acrilato de metila...( em vez de "..feita a adição lenta da acrilonitrila...")

\section{Página 70, 20 parágrafo - 5a linha}

..o telureto $\underline{68}$ foi obtido com... (em vez de "...o telureto $\underline{67}$ foi obtido com...")

\section{Página $72,1^{\circ}$ parágrafo - 5a linha}

Sem controle estereoquímico.. (em vez de "Sem controle estérico..") 